\title{
A TRANSPORT MECHANISM OF MERCURY INTO OVARIAN FOLLICLES IN LAYING QUAIL
}

\author{
Masakazu NISHIMURA and Norimoto URAKAWA \\ Department of Veterinary Pharmacology, Faculty of Agriculture, \\ University of Tokyo, Bunko-ku, Tokyo, Japan \\ Received for publication March 7, 1972
}

It has been reported that mercury given to laying birds as alkoxy mercury compounds (1) or inorganic mercury $(1,2)$ was transported into ovarian follicles. In the previous report, Nishimura and Urakawa (3) have suggested that inorganic mercury given to laying quail probably binds to a serum protein which is biosynthesized in the liver in response to estrogens, and the bound mercury is transported to deposit in the ovarian follicles.

In the present paper, the mercury-bound protein in the egg yolk and the serum from laying quail was studied to clarify a transport mechanism of mercury into ovarian follicles, especially a protein-bound carrying system.

\section{METHODS}

Quail (Conmix coturnix japonica) of both sexes used in the experiment were of the JQ-NIBS closed colony strain and were supplied by the Nippon Institute for Biological Science (Tachikawa, Tokyo). Male quail were 6 to 8 weeks old and weighed approx. $90 \mathrm{~g}$. Laying quail were 8 to 20 weeks old and weighed approx. $130 \mathrm{~g}$. The laying quail selected for experiment had a history of producing more than five eggs a week (2).

Estrogenization: Eight wecks old male quail were injected intramuscularly with a single dose of $0.2 \mathrm{mg}$ of aqueous suspending estradiol benzoate $(1,3,5$, (10)-estratriene3, 17-diol-3-monobenzoate) (Teikoku Zoki Co., Ltd., Tokyo) in a volume of $0.2 \mathrm{ml}$ per $100 \mathrm{~g}$ of body wt $48 \mathrm{hr}$ before radiomercury administration.

Serum preparation: Laying quail with a hard shell egg in uterus and male quail with or without estrogenization were injected with radioactive mercuric nitrate $\left({ }^{203} \mathrm{Hg}\left(\mathrm{NO}_{3}\right)_{3}\right.$, $8.65 \mathrm{mCi} / \mathrm{mg} \mathrm{Hg}$, the New England Nuclear corporation) into the jugular vein. The dose of ${ }^{203} \mathrm{Hg}\left(\mathrm{NO}_{3}\right)_{2}$ for a bird was $0.05 \mathrm{mg} \mathrm{Hg}$ per $100 \mathrm{~g}$ of body wt in a volume of $0.1 \mathrm{ml}$ in $0.01 \mathrm{~N} \mathrm{HNO}_{3}$ solution. The dose of mercuric nitrate had no inhibitory effect on egg production. Three hr after the injection of radiomercury, all birds were sacrificed by decapitation for a collection and preparation of serum sample.

Egg yolk preparation: Laying quail were injected with ${ }^{203} \mathrm{Hg}\left(\mathrm{NO}_{3}\right)_{2}$ in the dose of 0.05 $\mathrm{mg} \mathrm{Hg}$ per $100 \mathrm{~g}$ of body wt for a bird. The second to fifth or the sixth eggs laid after the injection of radiomercury were collected, and the egg yolk was separated. About

This work was partly supported by a research grant from the Ministry of Education, Japan 
$2 \mathrm{~g}$ of the yolk separated from fresh eggs was suspended in two volumes of distilled water and centrifuged at 3,000 r.p.m. for $60 \mathrm{~min}$. The precipitate and supernatant fractions were named as a yolk granule fraction (YGF) and a water-soluble fraction (WSF), respectively.

Trichloroacetic acid precipitation of serum and yolk: Each of sera or yolk samples prepared as described above was suspended in two volumes of $15 \%$ trichloroacetic acid (TCA) solution, stirred with great force for $20 \mathrm{~min}$ and centrifuged at 4,000 r.p.m. for $30 \mathrm{~min}$. After the supernatant was decanted, the precipitate was resuspended in two volumes of $10 \%$ TCA solution, stirred for $20 \mathrm{~min}$ and centrifuged as described above. A mixture of the first and second supernatant fractions was named as a trichloroacetic acid fraction (TCAF). The precipitate removed of the TCAF was washed three times with $10 \mathrm{ml}$ of ethylalcohol-ether mixture (1:1 by vol.), twice with $10 \mathrm{ml}$ of ethylalcohol and twice with $10 \mathrm{ml}$ of ethylalcohol-ether mixture (1:1 by vol.) to remove lipids. A combined extract of lipids fraction was named as an ethylalcohol-cther fraction (ETOHEth $F$ ) and the precipitate remained was named as a precipitate fraction (PF).

Ultracentrifugation of scrum and yolk: Laying quail and estrogenized male and unestrogenized male quail were administered with ${ }^{203} \mathrm{Hg}\left(\mathrm{NO}_{3}\right)_{3}$. The serum obtained from each bird was ultracentrifuged (Hitachi 55p-2, Hitachi Seisakusho Co., Ltd., Tokyo) at $175,300 \times \mathrm{g}$ for $5 \mathrm{hr}$, then the 5 aliquots in equal volume of the content in the butyratecentrifuge tube were successively taken out by micropipette from upside to the bottom. Each of the aliquots was named as fraction I-V respectively in the order of suction.

The yolk prepared from fresh egg as described above was divided into yolk plasma and yolk granules by ultracentrifugation at $100,000 \times \mathrm{g}$ for $3 \mathrm{hr}$ without dilution (4). The yolk plasma was decanted carefully by the use of micropipette.

Electrophoresis of serum and yolk: Serum in a volume of $2.4 / 4$ was placed on a cellulose acetate strip (Jookoo Sangyo Co., Ltd., Tokyo) of $3 \mathrm{~cm}$ width and $5 \mathrm{~cm}$ length and electrophorescd in the veronal buffer at $\mathrm{pH} 8.6(n=0.06)$ for $60 \mathrm{~min}$ at $0.6 \mathrm{~mA}$ per $1 \mathrm{~cm}$ width of the strip. After electrophoresis, the strip was divided longitudinally into two halves by scissors, one half was stained to detect proteins with Ponceau-3R stain (Jookoo Sangyo Co., Ltd., Tokyo), the other was stained to detect phosphorus by spraying $2.5 \%$ ammonium molybdate in $5 \mathrm{~N}$ sulfuric acid solution and then lighting with ultraviolet ray. Soon after the staining the distribution of ${ }^{203} \mathrm{Hg}$ on each strip was assayed by paper radiochromatogram scanner (Tokyo Atomic Co., Ltd., Tokyo).

YGF prepared from water suspension of yolk by centrifugation was added to two volumes of $10 \%$ sodium chloride solution and dialyzed against borate buffer at $\mathrm{pH} 8.6$ $(n=0.1)$ for $24 \mathrm{hr}$ at $4 \mathrm{C}$. Granular substances in the dialyzed cellulose tube were scdimented by the use of centrifuge to obtain clear supernatant. Proteins in the supernatant were separated by electrophoretic technique using the borate buffer.

Successive dilution of yolk gramules fraction in magnesium sulfate solution: The YGF was added $0.4 \mathrm{M}$ magnesium sulfate and insoluble substances were discarded. The solution of YGF in $0.4 \mathrm{M}$ magnesium sulfate was diluted with distilled water to make stepwise $0.2,0.1,0.05$ and $0.025 \mathrm{M}$ magnesium sulfate concentrations (5). Four precipitate 
fractions obtained at each step of dilutions were saved, and the last supernatant fraction $(\mathrm{SN})$ was assayed for determination of radiomercury.

In another experiment, each of the four precipitates obtained by the successive dilution of YGF was added to an equal volume of $10 \%$ sodium chloride solution, dialyzed against borate buffer $\mathrm{pH} 8.6(f=0.1)$ for $24 \mathrm{hr}$ at $4 \mathrm{C}$ and electrophoresed to separate proteins. After staining protein and phosphorus, each of the cellulose acetate strips was autoradio graphed for detecting the location of radioactivity.

Incubation of yolk gramules fraction with radionercury in vitro: Five grams of fresh yolk of quail's or hens' egg was suspended in two volumes of distilled water, stirred with great force for $20 \mathrm{~min}$ and centrifuged at 3,000 r.p.m. for $60 \mathrm{~min}$. After discarding the supernatant, the precipitate was added to an equal volume of $10 \%$ sodium chloride solution and insoluble substances were discarded. ${ }^{203} \mathrm{Hg}$-labelled yolk granules was obtained by an incubation of the sodium chloride solution of $\mathrm{YGF}$ with ${ }^{203} \mathrm{Hg}\left(\mathrm{NO}_{3}\right)_{3}$ for $5 \mathrm{hr}$ at $4 \mathrm{C}(2.5 \mu \mathrm{g} \mathrm{Hg} / \mathrm{g}$ wet wt of yolk granules, equivalent to $20 / \mathrm{Ci})$ and discarding insoluble substances. The labelled yolk granules were diluted 10 -fold with distilled water and centrifuged at 3,000 r.p.m. for $60 \mathrm{~min}$ at about $4 \mathrm{C}^{\circ}$. To the resultant water-insoluble precipitate was added $0.4 \mathrm{M}$ magnesium sulfate, diluted stepwise with distilled water, and proteins in each of the precipitate dialyzed against borate buffer and separated using the electrophorclic technique as described above.

Determination of radiomercury: All samples were weighed and subjected to the detection of radioactivity of gamma emitter by a well type scintillation detector (Tokyo Atomic Co., Ltd., Tokyo). The amount of radiomercury contained in each sample was expressed as a percentage to the dose administered.

\section{RESULTS}

Distribution of ${ }^{203} \mathrm{Hg}$ in scrum fractions

Fig. 1 shows the distribution of ${ }^{213} \mathrm{Hg}$ among trichloroacetic acid fraction (TCAF), ethylalcohol-ether fraction (ETOH-Eth $F$ ) and precipitate fraction (PF) in each of the sera from laying, estrogenized male and unestrogenized male quail administered with ${ }^{203} \mathrm{Hg}$ $\left(\mathrm{NO}_{3}\right)_{2}$. Large amounts of ${ }^{2 \cdot 13} \mathrm{Hg}$ in the whole serum were found with the estrogenized male and laying quail, while a much less amount was found with unestrogenized male quail. In all sera, the most of radiomercury was detected in the PF.

In the centrifugal experiments, the largest amount of ${ }^{213} \mathrm{Jg}$ in the serum was determined in the $\mathrm{V}$ fraction, and less in the I to IV fractions (Fig. 2). In the estrogenized male and laying quail, more than $60 \%$ of radioactivity in the whole serum was distributed in the $\mathrm{V}$ fraction. From the above results, it is suggested that ${ }^{203} \mathrm{Hg}$ binds to the well-sedimenting protein(s) by ultracentrifugation in the serum of the laying quail and increases in the serum of the estrogenized male quail.

Individual serum protein was separated by electrophoretic technique and the distribution of radioactivity among separated protcins on cellulose acetate strip was assayed (Fig. 3). Protein-positive as well as phosphorus-positive bands were observed with the 


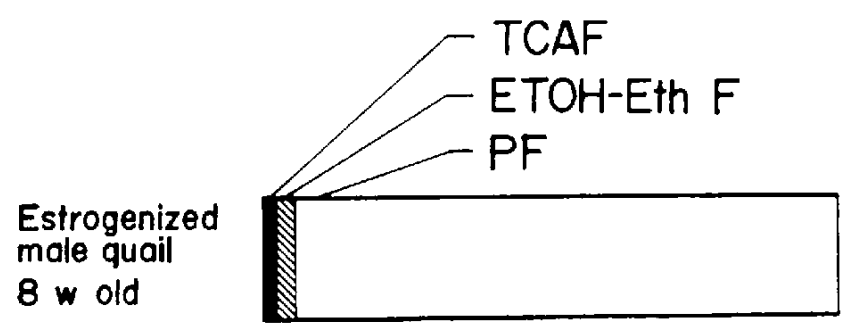

\section{Laying \\ quail \\ $12 w$ old}

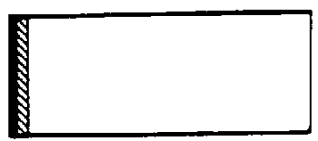

\section{Unestrogenized male qual $8 w$ old}

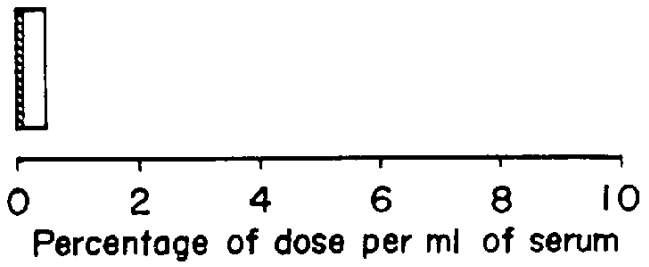

Fic. 1. Distribution of radiomercury in fractions of sera.

TCAF; trichloroacetic acid fraction

ETOH-Eth ; ethylalcohol-ether fraction

$\mathrm{PF}$; precipitate fraction

See text about percentage of dose'nul of serum. Number of observations is six.

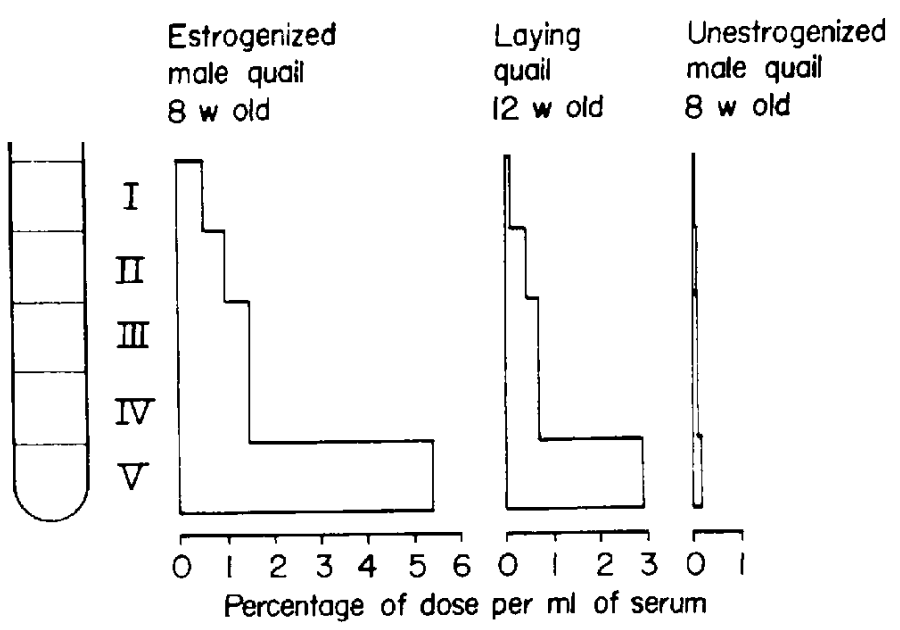

FIci. 2. Distribution of radiomercury in ultracentrifugal fractions of sera.

Each point represents a mean of six experiments.

laying and the estrogenized male quail but not with the unestrogenized male quail. The protein-postitive band corresponded to the phosphorus-positive one in electrophoretic mobility in the veronal buffer, and the mobility was relatively small. The location of radinactivity on the strip coincided with the protcin- and phosphorus-positive band. These 


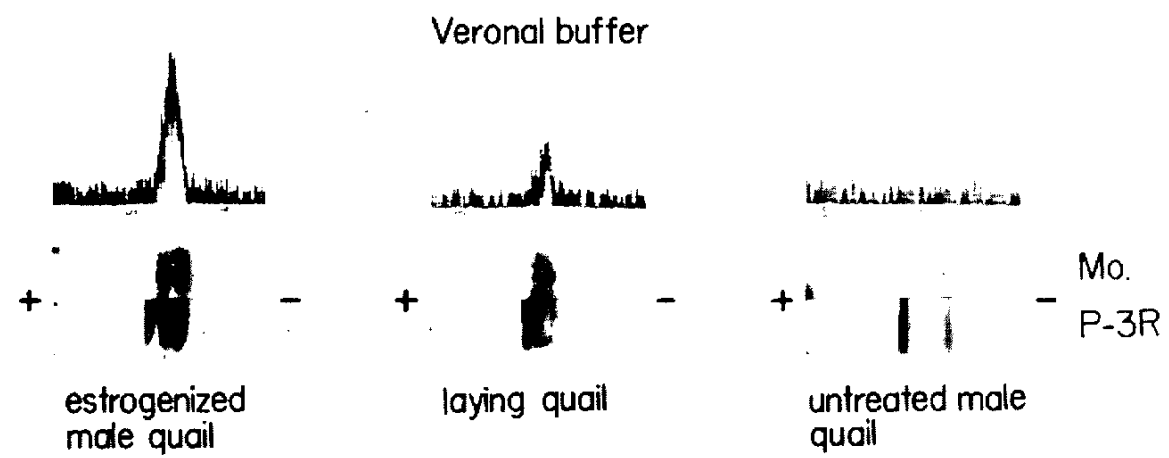

Fici. 3. Cellulose acetate electrophoregrams of sera and distribution of radiomercury on the strips.

Mo; phosphorus stain by ammonium molybdate

$\mathrm{P}-3 \mathrm{R}$; protein stain by Ponceau $3 \mathrm{R}$

Veronal buffer: pH $8.6(, \cdots 0.06\}$

Radioactivity on the strips was detected by means of paper radiochromatogram scanning.

data suggest the possibility that mercury binds to a protein which contains phosphorus and appears in the sera of the laying and the estrogenized male quail in response to estrogens.

Mode of existence of "in $\mathrm{Hg}$ in yolk

Yolks of the second to fourth egg laid after radiomercury injection were divided into TCAF, ETOH-Eth F and PF and the radioactivity in these fractions was determined (Fig. 4). The amount of ${ }^{2 n g} \mathrm{H}$ in the yolk was the largest with the third egg among the three. In all three eggs. most of the radioactivity was detected in the PF but little in the TCAF and the ETOH-Eth F.

Yolks of the second to sixth eggs laid after injection of radiomercury were divided into the WSF and the YGF, and radioactivity in the Iwo fractions was detected (Fig. 5). In all of these eggs, most of the radioactivity in the yolk was detected in the YGF.

Four precipitate fractions from the YGF were prepared by the magnesium sulfate dilution technique, and the radioactivity in the fractions was assayed (Fig. 6). The amount of ${ }^{213} \mathrm{Hg}$ in each fraction was found to be large according to the following order: precipitate at the magnesium sulfate concentration of $0.05 \mathrm{M}, 0.1 \mathrm{M}, 0.025 \mathrm{M}, 0.2 \mathrm{M}$, the WSF and the SN. Fig. 7 shows the results in the electrophoresis of the four precipitate fractions and YGF as well as the autoradiographic distributions of "Hg on the cellulose 


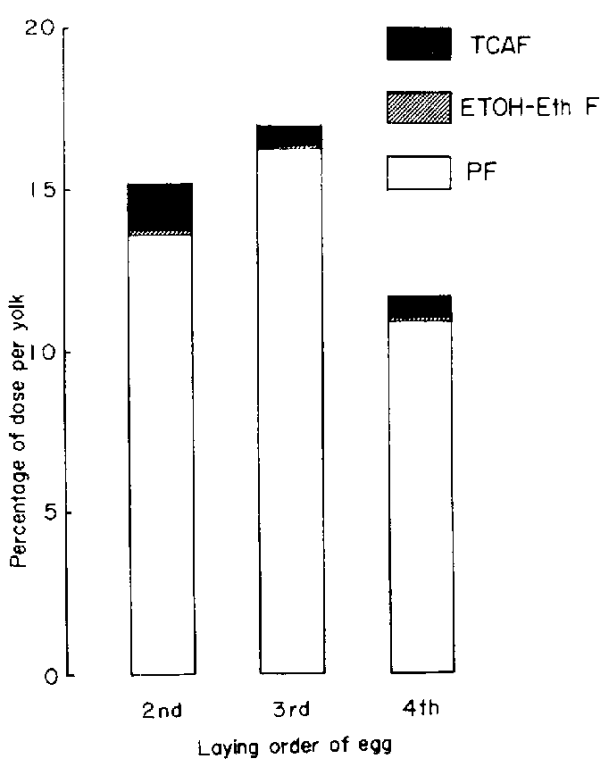

Fici. 4. Distribution of radiomercury in egg yolk in fractions: TCAF, ETOH-Eth $\mathrm{F}, \mathrm{PF}$.

A mean of six experiments is shown.

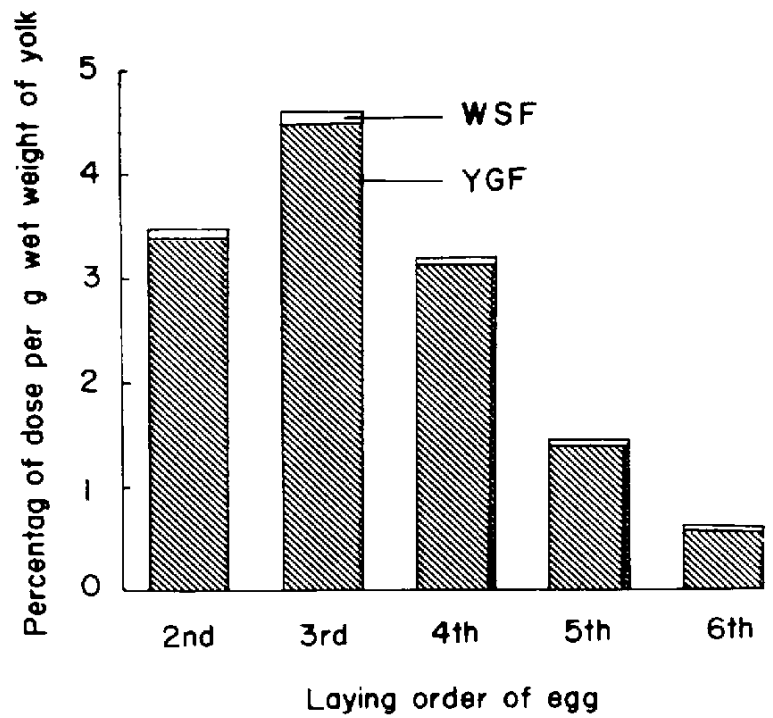

Fici. 5. Distribution of radiomercury in WSF (watcr-soluble fraction) and YGF (yolk granules fraction) of egg yolk.

Each point represents a mean of five experiments.

acetate strip. In all of the five strips, radioactivity was detected only in the single proteinand phosphoruspositive band. This coincidence in location of radioactivity and a protein was confirmed by in limo experiments in the yolk of both hen and quails egg (Figs. 8 9). 


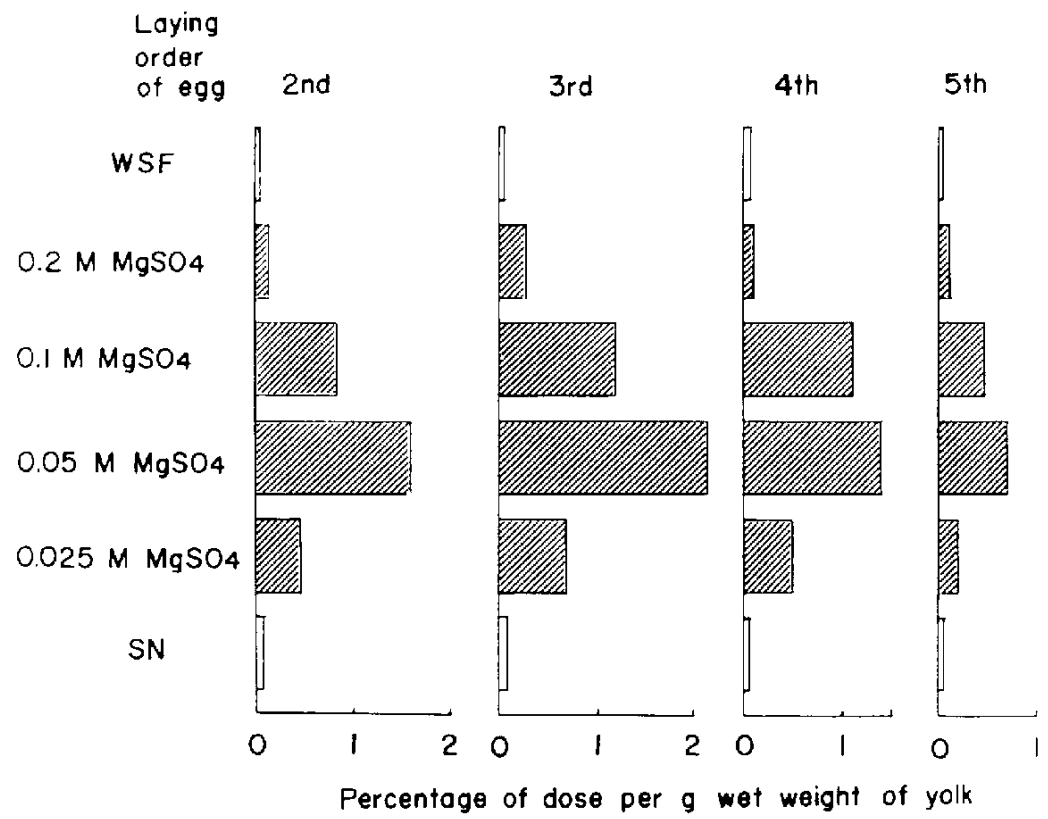

Fic. 6. Separation of egg yolk granule proteins by magnesium sulfate dilution method and distribution of radiomercury.

Each point represents a mcan of five experiments.

WSF; water-soluble fraction

SN; last supernatant fraction

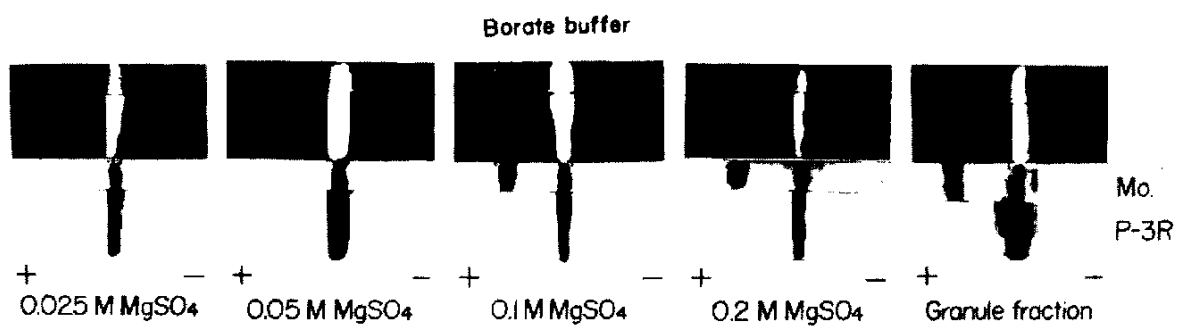

FIG. 7. Cellulose acetate electrophoregrams of water-insoluble yolk granule fraction and precipitate fractions obtained at $0.2 \mathrm{M}, 0.1 \mathrm{M}, 0.05 \mathrm{M}$ and $0.025 \mathrm{M}$ magnesium sulfate and autoradiograms of the strips.

Mo: phosphorus stain by ammonium molybdate

P-3R : protein stain by Poncedu $3 R$

Upper : autoradiograms

Lower; electrophoregrams

The distribution of radioactivily in two fractions, a yolk plasma (supernatant) and yolk granules (sediment), prepared from the yolk undiluted with water by ullracentrifugation was studied (Fig. 10). In all of the second to fifth eggs laid after radiomercury administration. most of the radioativily was found in the yolk granules. It has been reported 


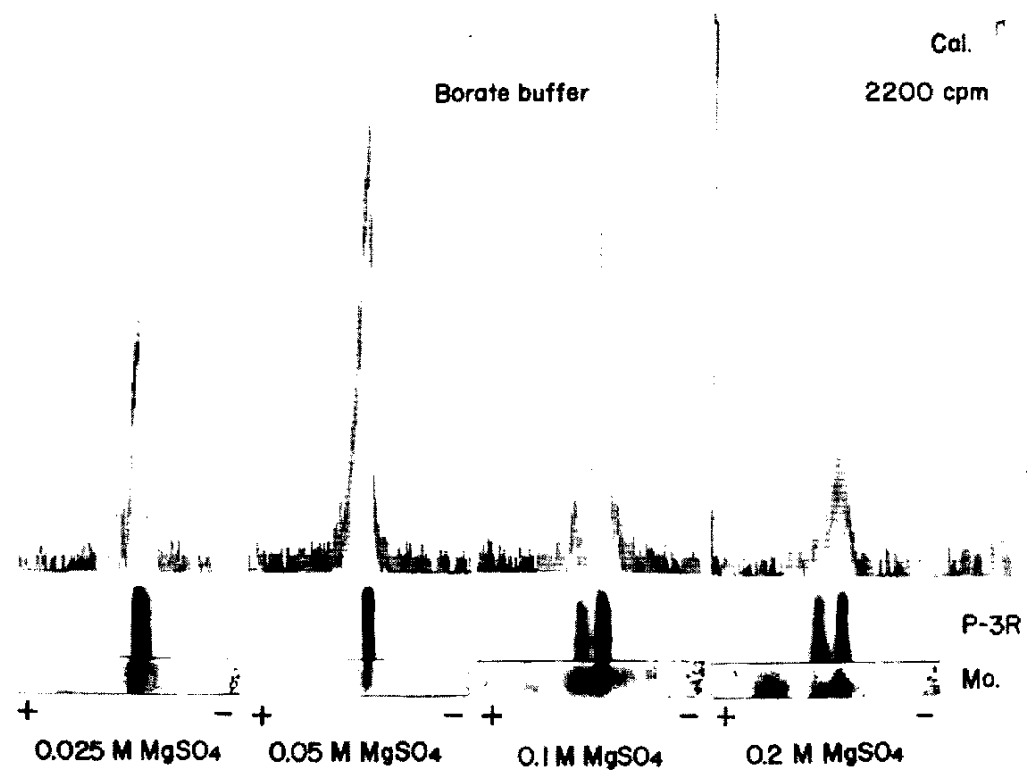

FIG. 8. Electrophoregrams and radioactivity of precipitates obtained by successive dilution of magnesium sulfate solution ef water-insoluble yolk proteins of quail's egg labelled with ${ }^{2 ! 3} \mathrm{Hg}$ in vitro.

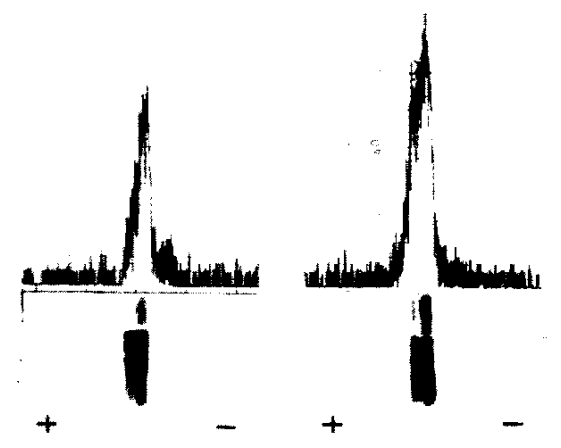

0025 M MgSO4
$0.05 \mathrm{M} \mathrm{MgSO} 4$

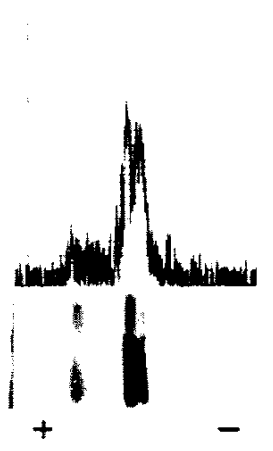

0.1 M Masos

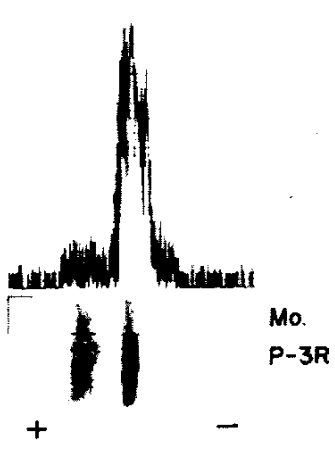

$0.2 \mathrm{M} \mathrm{MgSO} 4$

FIG. 9. Electrophoregrams and radioactivity of precipitates obtained by successive dilution of magnesium sulfate solution of water-insoluble yolk proteins of hen's egg labelled with $\mathrm{Hg}$ in vitro.

that the yolk of hens egg undiluted with water is divided ultracentrifugally into a yolk plasma which contains $\beta$-lipovitellin and yolk granules which contain 6 -lipovitellin (4). Our results suggest that the mercury-bound protein is probably a-lipovitellin. 


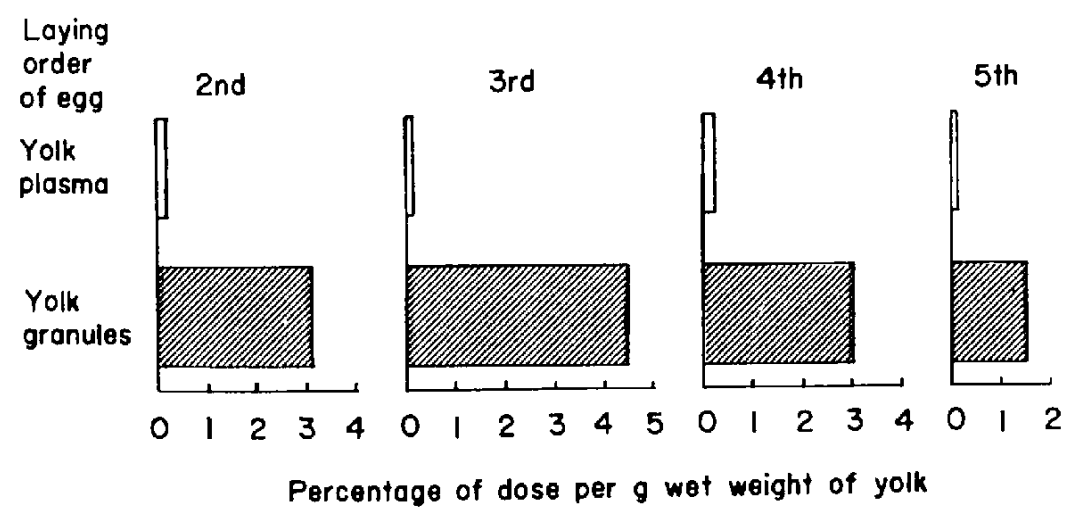

FIG. 10. Ultracentrifugation of undiluted egg yolk and distribution of radiomercury. Number of observations is six.

\section{DISCUSSION}

\section{Bound form of mercury in the serum}

From the present experiments, mercury in the sera of laying and estrogenized male quail appears to bind with a protein which had relativcly little electrophoretic mobility, contains phosphorus, sediments well by ultracentrifugation and appears in the serum in response to estrogenic activity. Little mercury was detected in the ethylalcohol-ether extractable lipid fraction of the sera. Many studies have noted that a new protein complex appeared in blood plasma of laying birds $(6,7)$ and of estrogenized birds $(8,9)$. The new protein complex consisted of phosphoprotein and lipoprotein $(10,11)$ was synthesized by liver in response to estrogens, then supplied to the ovarian follicles for construction the yolk proteins $(12,13)$. It has also been reported that this serum protein complex is obtained by electrophoresis as a slow-moving protein fraction rich in phosphorus from serum of laying or estrogenized birds (8) and is suggested as a lipovitellin-phosvitin $\gamma$-livetin complex (14). This protein complex had been found in the yolk by Joubert and Cook (15). From these and our data, it is probable that mercury bound firmly to the lipovitellin-phosvitin- $\gamma$-livetin complex, and the bound mercury was transported in the body. Bound form of mercury in yolk

The chemical aspects of yolk proteins and lipids were reviewed by Gilbert (16) as follows; Yolk proteins are divisible into three classes according to behaviour in the ultracentrifuge, namely, low-density, water-soluble and granular fractions. The low-density fraction termed as lipovitellenin in older literature is by far the most abundant, forming approx. $34 \%$ of the total yolk, containing more than $90 \%$ of the lipids and nearly $20 \%$ of the phosphorus. The water-soluble proteins termed as livetins form $10 \%$ of yolk solids and $30 \%$ of the protein. There are at least three components, termed as $\alpha$-, $\beta$ - and $\gamma$ livetins. The granular fraction contains all the lipovitellins and phosvitin of the yolk. Phosvitin contains nearly $70 \%$ of the yolk phosphorus as phosphoprotein, but forms only $4 \%$ of the total yolk solids. It also binds to approx. $75 \%$ of the yolk calcium. The highdensity part of the granular fraction contains lipovitellins ( $\alpha$-lipovitellin and $\beta$-lipovitellin) 
which form approx. $16 \%$ of the yolk solids and contain approx. $7 \%$ and $12 \%$ respectively of its lipid and phosphorus. Yolk lipids are almost exclusively restricted to the lipovitellins and the low-density fraction. In total, lipids form approx. $30 \%$ of the yolk and approx. 60 to $70 \%$ of yolk solids. Approx. $25 \%$ of lipovitellin is lipid. The low-density fraction contains approx. $80 \%$ lipid.

Mercury in the yolk existed in a protein contained phosphorus and in the waterinsoluble granule fraction as a slow-moving protein in electrophoresis. The mercurybound protein in the yolk is probably the lipovitellin-phosvitin- $\gamma$-livetin complex as suggested by Joubert and Cook (15) in the yolk experiments, however, it is unlikely that mercury binds to water-soluble protein such as livetins and an ultracentrifugal floating protein such as low-density lipoprotein. Joubert and Cook (5) found three proteins in the yolk granule fraction by utilizing the gradual magnesium sulfate dilution method, I) phosvitin which was rich in phosphorus (approx. 10\%) and detected in two precipitate fractions obtained at concentrations of $0.2 \mathrm{M}$ and $0.1 \mathrm{M}$ magnesium sulfate, 2) lipovitellins which contained phosphorus less than $1 \%$ and were detected in all of the four precipitate fractions by the magnesium sulfate dilution and 3) $\gamma$-livetin (water-soluble protein) which was also found in all of the four precipitate fractions but did not contain phosohorus. From these data, the mercury-bound protein in our experiments is presumed to be lipovitellin. Little mercury contained in the cthylalcohol-ether extractable lipid fraction suggests that the binding site of mercury to the lipovitellin is situated in the protcin moiety i.e. vitellin. In our study, a protein in yolk was found to behave as a single component with similar mobility in clectrophoresis on cellulose acetate to pure phosvitin prepared from egg yolk (Sigma Chemical Co., St. Louis, Missouri, U.S.A.), while it contained no radioactivity of ${ }^{203} \mathrm{Hg}$, suggesting that the binding of mercury with lipovitellin is specific.

Earlier studies on the carrier proteins in the plasma were reviewed by Butler (17). One of the remarkable propertics of many plasma proteins is their ability to combine selectively with nutrients, metabolites, hormones, drugs and toxic substances. This enables them to transport these molecules from the sites of production or absorption to the tissue where they are utilized, stored, catabolized or excreted. Albumin was reported to have an affinity for calcium as well as anions in the plasma of the non-laying fowl (18). It was also suggested that albumin is probably involved in the transportation of magnesium, copper and zinc in birds as well as man. Farvar and Cember (19) reported that mercury bound to albumin of the rat with in vitro experiments. Transferrin is known to bind with iron and to be responsible for its transport in the plasma to yolk in birds (20). It is now clear that phosvitin which appeared in the plasma prior to the onset of lay or following administration of estrogens and coincided with a great increase in the levels of calcium and iron in the plasma plays as important part in the transport of these metals, as well as phosphate to yolk $(18,21,22)$. Panic (22) reported that its affinity for iron is even greater than that of transferrin and it carrics at least $50 \%$ of the iron present in the plasma of the laying hen. It has been shown that lipoproteins carry fat-soluble vitamins and hormones and participate 
in the transport of calcium in the estrogenized cock and presumably in the laying hen as well (18). Magnesium may also be carried (23). It is known that there is a lipoprotein which is involved in the transport of selenium in chick plasma (24).

Most inorganic elements in the yolk are known to exist in bound form with one or other of the yolk protcinsor phospholipids (16). There is evidence that phosvitin has a high capacity for binding polyvalent metals, e.g. calcium (25) and iron (26) in the yolk as in the plasma. Tupper et al. (27) clarified that most zine in the yolk appears to form a complex with lipovitellin.

From the above knowledge, it is presumed that, in the serum, mercury as well as zine would bind to lipovitellin and calcium, iron and magnesium to phosvitin in the lipovitellinphosvitin- $r$-livetin complex synthesized in the liver by the action of estrogens and the protein-bound metals would be then transported via the circulation and deposited in the ovarian follicles.

\section{SUMMARY}

An investigation was undertaken on a transport mechanism of mercury into ovarian follicles, especially on a protein-bound carrying system, in laying quail. Sera and egg yolks from laying quail injected intravenously with ${ }^{203} \mathrm{Hg}\left(\mathrm{NO}_{3}\right)_{2}$ were subjected to protein fractionation by means of ultracentrifugation and electrophoresis followed by the radioassiay of ${ }^{2 i 3} \mathrm{Hg}$ in the fractions.

Mercury bound to a protein containing phosphorus in the sera of laying and cstrogenized male quail as well as in the yolk. The protein bound with mercury in the yolk was presumed to be lipovitellin which is a constituent of lipovitellin-phosvitin- $\gamma$-livetin complex by the magnesium sulfate dilution technique.

It is suggested that a substantial part of the mercury in the serum of laying quail binds to lipovitellin of the lipovitellin-phosvitin- $\gamma$-livetin complex appears in the serum during the laying period, after which the bound-mercury is transported into ovarian follicles.

Acknowledgcments: The authors wish to thank Dr. K. Ifomma of the Department of Veterinary Physiology, Faculty of Agriculture, University of Tokyo, and Dr. H. Karaki of the authors' Department for valuable advice in this work.

\section{REFERENCES}

1) Rissanin, K. and Mifttinev, J.K.: Amt. Agr. Fent. 7 (Suppl. 1), 22 (1968)

2) Nishimura, M., Urakawa, N. ANd Ikeda, M.: Jap. J. Pharmac. 21, 651 (1971)

3) Nishimura, M. and Urakawa, N.: Jap. J. Pharmac. 22, (1972)

4) Hasegawa, K.: Bull. Agr. Chem. Soc. Japan 34, 879 (1960) (In Japanese)

5) Joubrert, F.J. And Cook, W.H.: Cal. J. Biochem. Physiol. 36, 389 (1958)

6) Laskowski, M.: Biochem. Z. 278, 345 (1935)

7) RoFrki, R.R. AND Hugills, J.S.: J. biol. Chem. 108, 79 (1935)

8) McKinley, W.P., Oliver, W.I., Maw, W.A. and Common, R.H.: Proc. Soc.exp. Biol. Med. 84, $346(1953)$

9) MCDONald, M.R. AND RidDLe, O.: J. biol. Chem. 159, 445 (1945) 
10) SCHJEIDE, O.A. AND URIST, M.R.: Science 24, 1242 (1956)

11) Schjeide, O.A. ANd URIST, M.R.: Nature 188, 291 (1960)

12) Hosoda, T., Kaneko, T., Mogi, K. and Abe, T.: Poult. Sci. 34, 9 (1955)

13) Hosoda, T., Abf, T. and Kaneko, T.: Proc. Soc. exp. Biol. Med. 108, 234 (1961)

14) Common, R.H. AND Mok, C-C: Nature 183, 1811 (1959)

15) Joubert, F.J. AND Cook, W.H.: Can. J. Biochem. Physiol. 36, 399 (1958)

16) Gilbert, A.B.: Physiology and Biochemistry of the Domestic Fowl, Edited by Bell, D.J. AND Frf.Fman, B.M., p. 1379, Academic Prcss, London and New York (1971)

17) Butler, E.J. : Physiology and Biochemistry of the Domestic Fowl, Edited by BfLl, D. J. and FrfFman, B.M., p. 933, Academic Press, London and New York (1971)

18) Urist, M.R., Schueide, O.A. And MCLean, F.C.: Endocrinol. 63, 570 (1958)

19) Farvar, M.A. and Cember, H.: J. Occup. Med. 11, 77 (1969)

20) Williams, J.: Biochem. J. 83, 355 (1962)

21) Ramsay, W.N.M. and Camphetl, E.A.: Biochem. J. 58, 313 (1954)

22) Panic, B.: Trace Element Metabolism, Edited by MiLls, C.F., p. 324, E. and S. Livingstone, Edinburgh (1970)

23) ScIJjerde, O.A.: Progress in the Chemistry of Fats and the Lipids, Edited by Holman, R.T., Lindberg, W.O. and Malkin, T., Vol. 6, p. 253, Pergamon Press, Oxford, London New York and Paris (1963)

24) Disal, I.D. And SCoTt, M.L.: Arch. Biochem. Biophys. 110, 309 (1945)

25) Schueide, O.A. ANd URIst, M.R.: Exp. Cell. Res. 17, 84 (1959)

26) Nalkett, J.A.E., Peters, T. and Ross, J.F.: J. biol. Chem. 231, 187 (1958)

27) Tuppre, R., Watts, R.W.E. and Wormall, A.: Biochem. J. 51, ix (1952) 